\title{
Placebos could improve link between medical outlooks
}

\section{Paul Smaglik, Washington}

Study of the placebo effect - the role of medically inactive treatments in healing could help to bridge the divide between mainstream and alternative medicine, a National Institutes of Health (NIH) meeting was told this week.

Stephen Strauss, director of the National Center for Complementary and Alternative Medicine, has been trying to heal the rift that has, if anything, deepened since Congress forced a reluctant NIH to research alternative medicine in 1992 . He is encouraged that 20 other NIH institutes and offices helped to organize the meeting, and that several institute directors took part.

Gerald Fischbach, director of the National Institute of Neurological Disorders and Stroke, described the placebo effect as complex and poorly understood. He suspects that it has some biological basis, perhaps involving specialized nerve cells that respond to the expectation of treatment.

Steven Hyman, director of the National Institute of Mental Health, said that the increasing acceptance of such concepts may explain why researchers are paying more attention to placebos. For example, there is growing evidence that repeated exposure to a stimulus can reconfigure the brain's circuitry.

But it may be difficult to tackle such issues until the study of placebos gains broader acceptance, and psychologists, neuroscientists and social scientists become more willing to join forces. The NIH now offers more interdisciplinary grants, but Hyman is worried that young scientists may shy away from

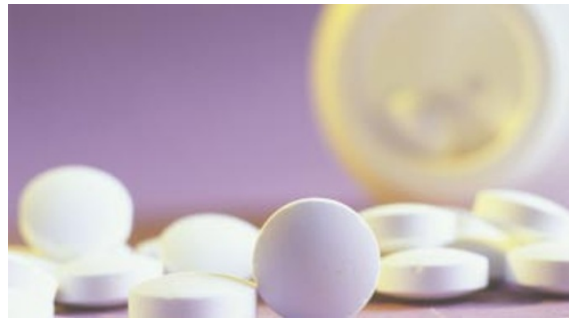

Sugaring the pill: research may help convince those who find the placebo effect hard to swallow.

the problem, because of the potential for failure in an untested field.

The presence of so many senior NIH researchers at the meeting contrasted with the past hostility towards Strauss's centre. Former NIH director Harold Varmus tried unsuccessfully to cut its budget, even as the overall NIH budget rose. And the institute's last director, Wayne Jonas, was often a lightning rod for criticism. Strauss has received broader support because he appears to be trying evaluate alternative medicine using the best available science, and he sees the placebo effect as key.

"It is a very important issue for our institute because of all the preconceived biases as to how these traditional therapies must be operating — that they must be operating merely through the placebo effect," Strauss says.

David Korn, vice-president for research at the American Association of Medical Colleges, said that Strauss is doing a good job in narrowing the gap between orthodox and alternative physicians. And he applauds Strauss's focus on the placebo effect, which he believes will help all physicians.

\section{Biotech report dubbed 'worthless'}

Haim Watzman, Jerusalem

Research directors at Israel's universities say that an upcoming government-sponsored report on biotechnology policy will be worthless because they were not consulted by its authors.

"The authors of the report are completely unaware of the reorganization the universities have undergone to take into account the needs of high-tech," says Yair Aharonowitz, vice-president and dean for research at $\mathrm{Tel}$ Aviv University.

Aharonowitz and colleagues at five other universities sent a letter of protest to Carmel Vernia, chief scientist at the Ministry of Industry and Trade. Earlier this year Vernia commissioned a report on the state of Israel's biotechnology industry from the Monitor
Group, a consulting firm. Although Monitor has until the end of the year to submit its report, the Israeli press has reported that it will call for the diversion of money from basic research to work with clearer commercial potential.

Any such diversion would be a "gross error", Menachem Magidor, president of the Hebrew University of Jerusalem, declared in a recent interview. Aharonowitz says that Monitor got all its information from industry, and made no contact with five of the six Israeli universities with life-science faculties.

Vernia declined to comment, but a spokesman said that he had "recommended that Monitor meet with the research vicepreston20000mandilathaganiolesictu of the process of writing its report".

\section{Researchers fail to find signs of life in 'living' particles}

\section{Alison Abbott, Munich}

Despite their tiny size, the purported pathogenic microorganisms dubbed 'nanobacteria' are still stirring big controversy in microbiological circles.

A report published in Proceedings of the National Academy of Sciences last month $(97,11511-11515 ; 2000)$ has failed to confirm biochemical signs of life in the apparently self-replicating particles.

Finnish biochemist Olavi Kajander of the University of Kuopio believes the particles, which are 50-500 nanometres in diameter, are a new type of microorganism. He says that they could be involved in kidney disease. (Nature 401, 105; 1999).

The particles all have coats of heavy hydroxyapatite, the mineral that forms teeth and kidney stones. According to Kajander, this coat makes them resistant to attack from environmental assaults - and also to standard microbial and biochemical analysis. But he says the particles appear to be living because microscope analysis reveals broad similarity to bacteria. He also says that they stain for DNA, using a modification of a standard method.

Now some of his experiments have been repeated independently. John Cisar of the US National Institutes of Health in Bethesda, and colleagues from the Food and Drug Administration, have created the particles and reproduced their selfpropagating properties.

But the researchers say that the particles' self-propagation and morphology can be explained in terms of microcrystallization, independent of any 'living' mechanism. They could not detect any nucleic acids or proteins in the particles. Moreover, the self-propagation was unaffected by sodium azide, which inhibits respiration. Cisar says that "there is a need for hard molecular evidence" to support a claim for a biological base.

Kajander and his colleagues, including some clinical researchers, counter that the special properties of nanobacteria mean that standard biochemical analyses are not necessarily applicable. "We have evidence that the particles are living," insists Neva Çiftçioglu, also at Kuopio. "We are not fanatics, we are scientists."

And Franklin Cockerill, chair of microbiology at the Mayo Clinic, Rochester, says he will continue trying to extract DNA from the nanobacteria. He hopes to sequence the genome for the particles, which, he suggests, could indicate the smallest number of genes required for life. 